\title{
Stage I Gastric Cancer AJCC v6
}

National Cancer Institute

\section{Source}

National Cancer Institute. Stage I Gastric Cancer A/CC v6. NCI Thesaurus. Code C7772.

Stage I includes: IA: (T1, NO, M0) and IB: (T1, N1, M0); (Ta/b, N0, M0). T1: T umor invades lamina propria or submucosa. T2: Tumor invades the muscularis propria or the subserosa. T2a: Tumor invades muscularis propria. T2b: Tumor invades subserosa. N0: No regional lymph node metastasis. N1: Metastasis in 1 to 6 regional lymph nodes. N2: Metastasis in 7 to 15 regional lymph nodes. M0: No distant metastasis. (AJCC 6th ed.) 